\title{
Mothers' Handwashing Knowledge as a Predictor of Diarrheal Disease Among Under-Five Children Visiting Pediatric Ward in University of Gondar Comprehensive Specialized Hospital, Northwest Ethiopia, 2019
}

This article was published in the following Dove Press journal: Pediatric Health, Medicine and Therapeutics

\author{
Zewudu Andualem (D) \\ Henok Dagne' \\ Asefa Adimasu Taddese ${ }^{2}$ \\ Baye Dagnew $\mathbb{1 D}^{3}$
}

'Department of Environmental and Occupational Health and Safety, Institute of Public Health, College of Medicine and Health Sciences, University of Gondar, Gondar, Ethiopia; ${ }^{2}$ Department of Epidemiology and Biostatistics, Institute of Public Health, College of Medicine and Health Sciences, University of Gondar, Gondar, Ethiopia; ${ }^{3}$ Department of Human Physiology, Sciences School of Medicine, College of Medicine and Health Sciences, University of Gondar, Gondar, Ethiopia

Correspondence: Zewudu Andualem; Henok Dagne

Department of Environmental and Occupational Health and Safety, Institute of Public Health, College of Medicine and Health Sciences, University of Gondar, Gondar, Ethiopia

Email zewuduandualem12@gmail.com; enoch2313@gmail.com
Background: Diarrheal disease is one of the leading causes of mortality and morbidity among under-five children in the world and often results from contaminated food and water. The aim of this study was to assess the prevalence of diarrheal disease among under-five children visiting the pediatric ward in University of Gondar Comprehensive Specialized Hospital and its association with their mothers' handwashing knowledge.

Methods: An institutional-based cross-sectional study was conducted from May to July 2019 among under-five children visiting the pediatric ward in University of Gondar Comprehensive Specialized Hospital. An interviewer-administered questionnaire was used to collect the data. Chart review was undertaken using a data abstraction form. A simple random sampling technique was used to select the study participants. Data were entered using Epi Info version 7 and analyzed using STATA version 14.0. A binary logistic regression analysis was employed between dependent and independent variables to determine association. The statistical significance was declared at $P<0.05$.

Results: In this study, the prevalence of diarrheal disease among under-five children visiting the pediatric ward in University of Gondar Comprehensive Specialized Hospital was 30.09\% (95\% CI: $(26 \%, 35 \%))$. Age of mothers (AOR=3.72, 95\% CI: $(1.67,8.28))$, mothers' educational status $(\mathrm{AOR}=0.44,95 \% \mathrm{CI}$ : $(0.23,0.80))$, malnutrition $(\mathrm{AOR}=6.72,95 \% \mathrm{CI}$ : $(3.44,13.11)$ ), and maternal knowledge of handwashing (AOR $=0.49,95 \% \mathrm{CI}:(0.27,0.90))$ were factors associated with diarrheal disease among under-five children.

Conclusion: The prevalence of diarrheal disease was higher in the current study, which is a major public health concern. Age of mothers, malnutrition, and mothers' handwashing knowledge and educational status were significantly associated with diarrheal disease of under-five children. In order to reduce diarrheal disease and improve child health, attention should be given to improving mothers' educational status and knowledge regarding handwashing.

Keywords: diarrheal disease, knowledge, under-five children

\section{Introduction}

By 2030, it is estimated that 4.4 million under-five children will die from infectious diseases annually and that $60 \%$ of those deaths will occur in sub-Saharan Africa. ${ }^{1,2}$ Globally, there are nearly 1.7 billion cases of childhood diarrheal disease and 
diarrhea kills about 525,000 under-five children every year. ${ }^{3}$ The majority of the mortality occurs in resource-constrained countries. ${ }^{3}$ In Ethiopia, the Ministry of Health lists diarrhea as the second leading cause of mortality. ${ }^{4}$

Diarrhea is defined as the passage of three or more loose or liquid stools per day (or more frequent passage than is normal for the individual). ${ }^{5}$ It can be categorized as acute or chronic diarrhea. ${ }^{6,7}$ Diarrhea still appears to be the main cause of child death in several countries, consisting of a discriminatory indicator of geographical areas characterized by precarious collective living conditions, typifying the so-called poverty ecosystem. ${ }^{8,9}$ In sub-Saharan Africa, diarrhea is the second most common cause of mortality and morbidity of under-five children. Only $40 \%$ of people living in urban settings had access to improved sanitation and $72 \%$ of people living in Ethiopia had no improved sanitation facilities. ${ }^{10}$ The problem is related to environmental, socioeconomic, and cultural factors, and low coverage and effectiveness of health services. These factors can determine marked differences in their evolution due to inequalities that undermine the profile of production and distribution of goods and services in different strata of the population. ${ }^{8}$

Studies in India have shown that mothers with good knowledge of hand hygiene can prevent diarrhea by $38.88 . \%,{ }^{11}$ and the counterpart spread of disease from hands will go a long way in increasing the prevalence of infectious diseases and unwashed hands leading to diarrhea, ${ }^{12}$ and handwashing with soap removes transient potentially pathogenic organisms from hands and it is not sufficient to wash hands with only water after critical events like defecation. ${ }^{11}$ In Pakistan, $85 \%$ of mothers had a lack of knowledge about the method of making Oral Rehydration Solutions (ORS) at home, due to which $60 \%$ of children were suffering from severe dehydration. ${ }^{13}$ In Ethiopia, $65.2 \%$ of mothers had good knowledge about prevention and home-based management of diarrhea among under-five children, ${ }^{14}$ and the promotion of hand washing in communities prevents onequarter of episodes of diarrhea with a higher effect size when soap is provided free of charge. ${ }^{15}$

The aim of this study was to assess the prevalence of diarrheal disease among under-five children and its association with mothers' handwashing knowledge among mothers attending the pediatric health service in University of Gondar Comprehensive Specialized Hospital, Northwest Ethiopia. The identification of prevalence and contributing factors for diarrhea is very important for the effective implementation of child health programs.

\section{Materials and Methods Study Design, Period, and Setting}

An institution-based cross-sectional study was conducted from May to July 2019 among under-five children visiting the University of Gondar Comprehensive Specialized Hospital pediatric ward. University of Gondar Comprehensive Specialized Hospital is located in Central Gondar Zone North West Ethiopian. This hospital serves more than 5 million people for Gondar city and the surrounding community. ${ }^{16}$

\section{Sample Size Determination and Sampling Procedure}

The sample size was determined using a single population proportion formula with the following assumptions: proportion ( $p$ ) $50 \%$ (there is no previous study) to estimate the true proportion with $95 \%$ confidence interval, $5 \%$ absolute precision $(d), Z$ (standard normal distribution), $\alpha$ (level of significance) and $z_{\frac{a}{2}}$ is 1.96 .

$$
n=\frac{\left(z \frac{a}{2}\right)^{2} * p(1-p)}{d^{2}} n=\frac{(1.96)^{2} * 0.5(1-0.5)}{(0.05)^{2}}=384
$$

Assuming 10\% non-response, we estimated the required sample size to be 422 . A simple random sampling technique was used to select the study participants from the pediatric ward in University of Gondar Comprehensive Specialized Hospital.

\section{Data Collection Tools and Procedures}

An interviewer-administered questionnaire was used to collect the data from mothers/caregivers. The questionnaire was adapted from previous similar studies ${ }^{17,18}$ and customized accordingly. The outcome variable was the diagnosed diarrhea of under-five children in the period of data collection, which was recorded directly from the children's medical chart. The independent variables included socioeconomic (residence, family size, mothers'/caregivers' age, educational status of mothers, occupation, mothers' handwashing practice, knowledge, and attitude) and childrelated (meningitis, malnutrition, acute respiratory infection (ARI), age, and gender of the child) factors. The questionnaire consisted of closed-ended questions. Initially, the questionnaire was written in English and then translated into the local language (Amharic); researchers then returned 
to the English language to check its consistency. Data collectors and supervisors were trained on tools for data collection, questioning methods, interview techniques, methods of verbal consent, and data collection precautions. Data collectors were five Nurses and supervisors were two Environmental health professionals.

\section{Data Processing and Analysis}

Data were entered using Epi Info version 7 and analyzed using STATA version 14.0. Summary statistics such as frequencies, proportions, mean, and standard deviation were computed. A binary logistic regression analysis was employed between dependent and independent variables. The statistical significance was declared at $P<0.05$.

\section{Results}

\section{Sociodemographic Characteristics of Children and Mothers}

A total of 422 mothers have been aimed at for this study and the response rate was $100 \%$. The mean age of mothers was $35.63 \pm 11.74$ years. Whereas, the mean age of the children was $34.63 \pm 13.18$ months. Of the mothers, $57.58 \%$ were married and $71.09 \%$ were literate. Above two-thirds $(66.05 \%)$ of mothers had good knowledge of handwashing (Table 1).

\section{Factors Associated with Diarrheal Prevalence Among Under-Five Children}

In this study the prevalence of diarrheal disease among under-five children visiting the pediatric ward in University of Gondar Comprehensive Specialized Hospital was 30.09\% (95\% CI: $(26 \%, 35 \%)$ ). Bivariable and multivariable logistic regression analyses were performed to identify factors associated with diarrheal disease among under-five children.

In the bivariable analysis, age of the child, age of mothers, educational status of mothers, malnutrition, and maternal handwashing knowledge were associated with diarrheal disease. Whereas, age of mothers, malnutrition, and maternal handwashing knowledge and educational status had an association with diarrheal disease in multivariable analysis.

Of the respondents, under-five children having mothers aged $\geq 43$ years were 3.72 (AOR=3.72, 95\% CI: (1.67, 8.28)) times more likely to get diarrheal disease compared with those whose mothers were aged 16-27 years.

Under-five children who had literate mothers were $56 \%(\mathrm{AOR}=0.4495 \% \mathrm{CI}:(0.23,0.80))$ less likely to
Table I Socio-Demographic Characteristics of Children and Mothers in University of Gondar Comprehensive Specialized Hospital, Northwest Ethiopia, 2019

\begin{tabular}{|c|c|c|c|}
\hline \multicolumn{2}{|l|}{ Variables } & \multirow{2}{*}{$\begin{array}{l}\begin{array}{l}\text { Frequency } \\
(\mathbf{n}=\mathbf{4 2 2})\end{array} \\
107 \\
104 \\
108 \\
96\end{array}$} & \multirow{2}{*}{$\begin{array}{l}\text { Percent } \\
\text { (\%) } \\
25.79 \\
25.06 \\
26.02 \\
23.13\end{array}$} \\
\hline $\begin{array}{l}\text { Age of child } \\
(n=4 \mid 5)\end{array}$ & $\begin{array}{l}2-26 \text { months } \\
27-36 \text { months } \\
37-46 \text { months } \\
47+\text { months }\end{array}$ & & \\
\hline Age of mothers & $\begin{array}{l}16-27 \text { years } \\
28-33 \text { years } \\
34-42 \text { years } \\
\geq 43 \text { years }\end{array}$ & $\begin{array}{l}106 \\
109 \\
107 \\
100\end{array}$ & $\begin{array}{l}25.12 \\
25.82 \\
25.36 \\
23.70\end{array}$ \\
\hline Residence & $\begin{array}{l}\text { Urban } \\
\text { Rural }\end{array}$ & $\begin{array}{l}238 \\
184\end{array}$ & $\begin{array}{l}56.40 \\
43.60\end{array}$ \\
\hline $\operatorname{Sex}(n=4 \mid 9)$ & $\begin{array}{l}\text { Male } \\
\text { Female }\end{array}$ & $\begin{array}{l}208 \\
211\end{array}$ & $\begin{array}{l}49.64 \\
50.36\end{array}$ \\
\hline $\begin{array}{l}\text { Monthly income } \\
(n=165)\end{array}$ & $\begin{array}{l}500-2500 \\
250 I-3500 \\
350 I-5100 \\
>5101\end{array}$ & $\begin{array}{l}47 \\
36 \\
41 \\
41\end{array}$ & $\begin{array}{l}28.48 \\
21.82 \\
24.85 \\
24.85\end{array}$ \\
\hline $\begin{array}{l}\text { Educational } \\
\text { status }\end{array}$ & $\begin{array}{l}\text { Unable to read } \\
\text { and write } \\
\text { Literate }\end{array}$ & $\begin{array}{l}122 \\
300\end{array}$ & $\begin{array}{l}28.91 \\
71.09\end{array}$ \\
\hline Marital status & $\begin{array}{l}\text { Currently not } \\
\text { married } \\
\text { Married }\end{array}$ & $\begin{array}{l}179 \\
243\end{array}$ & $\begin{array}{l}42.42 \\
57.58\end{array}$ \\
\hline ARI & $\begin{array}{l}\text { No } \\
\text { Yes }\end{array}$ & $\begin{array}{l}307 \\
115\end{array}$ & $\begin{array}{l}72.75 \\
27.25\end{array}$ \\
\hline Meningitis & $\begin{array}{l}\text { No } \\
\text { Yes }\end{array}$ & $\begin{array}{l}377 \\
45\end{array}$ & $\begin{array}{l}89.34 \\
10.66\end{array}$ \\
\hline Malnutrition & $\begin{array}{l}\text { No } \\
\text { Yes }\end{array}$ & $\begin{array}{l}319 \\
103\end{array}$ & $\begin{array}{l}75.59 \\
24.41\end{array}$ \\
\hline Knowledge & $\begin{array}{l}\text { Poor } \\
\text { Good }\end{array}$ & $\begin{array}{l}142 \\
280\end{array}$ & $\begin{array}{l}33.65 \\
66.35\end{array}$ \\
\hline Attitude & $\begin{array}{l}\text { Poor } \\
\text { Good }\end{array}$ & $\begin{array}{l}191 \\
231\end{array}$ & $\begin{array}{l}45.26 \\
54.74\end{array}$ \\
\hline Practice & $\begin{array}{l}\text { Poor } \\
\text { Good }\end{array}$ & $\begin{array}{l}160 \\
262\end{array}$ & $\begin{array}{l}37.91 \\
62.09\end{array}$ \\
\hline
\end{tabular}

have diarrheal disease than those who had illiterate mothers. Malnourished children were $6.72(\mathrm{AOR}=6.72$ 95\% CI: $(3.44,13.11))$ times more likely to have a diarrheal disease when compared with those non-malnourished. Children who had mothers with good handwashing knowledge were 51\% (AOR $=0.49$ 95\% CI: $(0.27,0.90))$ less likely to get the diarrheal disease 
Table 2 Associated Factors of Diarrheal Disease Using Bivariable and Multivariable Logistic Regression Analysis Among Under-Five Children in University of Gondar Comprehensive Specialized Hospital, Northwest, Ethiopia, 2019

\begin{tabular}{|c|c|c|c|c|c|}
\hline \multicolumn{2}{|l|}{ Variables } & \multicolumn{2}{|c|}{ Diarrheal Disease } & \multirow[t]{2}{*}{ COR $(95 \% \mathrm{Cl})$} & \multirow[t]{2}{*}{ AOR $(95 \% \mathrm{Cl})$} \\
\hline & & Yes & No & & \\
\hline Age of child & $\begin{array}{l}2-26 \text { months } \\
27-36 \text { months } \\
37-46 \text { months } \\
47+\text { months }\end{array}$ & $\begin{array}{l}24 \\
28 \\
31 \\
42\end{array}$ & $\begin{array}{l}83 \\
76 \\
77 \\
54\end{array}$ & $\begin{array}{l}\text { I } \\
\text { I.27 }(0.68,2.38) \\
1.39(0.75,2.58) \\
2.68(1.46,4.93)\end{array}$ & $\begin{array}{l}\text { I } \\
\text { I.I }(0.55,2.33) \\
\text { I.I3(0.55, 2.34) } \\
2.02(0.96,4.23)\end{array}$ \\
\hline Age of mothers & $\begin{array}{l}16-27 \text { years } \\
28-33 \text { years } \\
34-42 \text { years } \\
\geq 43 \text { years }\end{array}$ & $\begin{array}{l}25 \\
23 \\
30 \\
49\end{array}$ & $\begin{array}{l}81 \\
86 \\
77 \\
51\end{array}$ & $\begin{array}{l}\text { I } \\
0.86(0.45,1.64) \\
1.26(0.68,2.33) \\
3.11(1.71,5.64)\end{array}$ & $\begin{array}{l}\text { I } \\
1.09(0.52,2.30) \\
1.35(0.64,2.85) \\
2.51(1.20,5.24)^{*}\end{array}$ \\
\hline Educational status of mothers & $\begin{array}{l}\text { Unable to read and write } \\
\text { Literate }\end{array}$ & $\begin{array}{l}58 \\
69\end{array}$ & $\begin{array}{l}64 \\
231\end{array}$ & $\begin{array}{l}\mathrm{I} \\
0.33(0.2 \mathrm{I}, 0.5 \mathrm{I})\end{array}$ & $0.44(0.23,0.80)^{*}$ \\
\hline Malnutrition & $\begin{array}{l}\text { Yes } \\
\text { No }\end{array}$ & $\begin{array}{l}19 \\
108\end{array}$ & $\begin{array}{l}84 \\
211\end{array}$ & $\begin{array}{l}2.26(1.30,3.91) \\
I\end{array}$ & $\begin{array}{l}6.72(3.44,13.11)^{* *} \\
I\end{array}$ \\
\hline Mothers' handwashing Knowledge & $\begin{array}{l}\text { Good } \\
\text { Poor }\end{array}$ & $\begin{array}{l}71 \\
56\end{array}$ & $\begin{array}{l}209 \\
86\end{array}$ & $\begin{array}{l}0.52(0.34,0.80) \\
\text { I }\end{array}$ & $\begin{array}{l}0.49(0.27,0.90)^{*} \\
\text { । }\end{array}$ \\
\hline
\end{tabular}

Notes: *Significant at $P<0.05$. **Significant at $P<0.001$.

than those with mothers of poor handwashing knowledge (Table 2).

\section{Discussion}

In the present study, the prevalence of diarrheal disease among under-five children visiting University of Gondar Comprehensive Specialized Hospital pediatric ward was $30.09 \%$. The prevalence in this study is in line with previous studies in Jimma zone, Ethiopia, ${ }^{19}$ Jigjiga, Ethiopia, ${ }^{20}$ and in rural Burundi. ${ }^{21}$ However, it is higher than prevalence reports from $\operatorname{Iran}^{22}$ and India, ${ }^{23}$ and lower than studies conducted in Kenya ${ }^{24}$ and Ghana. ${ }^{25}$ The variation might be due to the differences in the setting of the study, the economic status of the study participants, and the variety of the respondents as our study participants were mothers visiting the hospital pediatric ward.

In this study, the knowledge of mothers about handwashing was $66.05 \%$, which is in line with a study conducted in Nigeria $(67.7 \%),{ }^{26}$ lower than in other studies conducted in Nigeria (72.4\%), ${ }^{27}$ India (83.14\%), ${ }^{11}$ Indonesia (83.8\%), ${ }^{17}$ Ethiopia (92\%), ${ }^{28}$ and India (96.7\%). ${ }^{29}$ The possible explanation could be that the difference in study setting, level of education, economic status, and social norms might be responsible for the variation of knowledge.

Under-five children whose mothers were aged 43 years and above were 3.72 times more likely at risk of diarrheal disease when compared with those having mothers aged 16-27 years.
This might be due to younger mothers exhibiting more positive attitudes than the elderly. This can also be associated with education, as younger women are more educated than elderly mothers and mothers can understand better the importance of child health if they are educated. ${ }^{30}$

In this study, under-five children who had literate mothers were $56 \%$ less likely to get diarrheal disease when compared with those who had illiterate mothers. The finding of this study is similar to previous studies. ${ }^{31-33}$ Education can raise awareness of diarrheal disease transmission and methods of prevention. As a result, educated women are able to seek and follow health care providers' dictates. Maternal training increases the mothers' response to children's diseases. Literacy for mothers affects hygiene practice, feeding children, weaning, and sanitation, which are, in turn, important factors for childhood diarrhea. ${ }^{34}$

Malnourished children were 6.72 times more likely to have diarrheal disease than those non-malnourished. This is supported by other studies. ${ }^{35,36}$ In general, malnourished children are more prone to persistent and infectious diarrhea, and also have an impaired immune function. Persistent diarrhea is responsible for serious morbidity and proven risk of a dangerous cycle of diarrhea and malnutrition. ${ }^{37}$ The magnitude of the impact is potentially altered by other variables such as etiology and clinical diarrhea, the source and adequacy of dietary intake, diagnosis, and feeding practices. 
Children who had mothers with good handwashing knowledge were $51 \%$ less likely to have diarrheal disease when compared with those with mothers of poor handwashing knowledge. The finding of this study is in line with the findings of other studies. ${ }^{18,38,39}$ Mothers' knowledge regarding causes of diseases, signs, and symptoms, prevention and control is very essential, thereby decreasing morbidity and mortality due to diarrhea. In this study, it is seen that mothers having higher education showing better knowledge about diarrheal disease in the prevention and management of diarrhea. ${ }^{18}$

\section{Conclusions}

Our study findings of diarrheal disease prevalence among under-five children were significantly higher compared to some other similar studies. Age of mothers, malnutrition, and mothers' handwashing knowledge and educational status had a significant association with under-five diarrheal disease. In order to reduce the prevalence of diarrhea and improve child health, attention should be given to improving mothers' educational status and hand hygiene knowledge to integrate diarrhea and malnutrition management efforts.

\section{Ethics Approval and Informed Consent}

Ethical clearance was approved and obtained from the ethics review committee of the Department of Environmental and Occupational Health and Safety (Ref No_EOHS/769/2011). Then, the official permission letter was obtained from Department of Environmental and Occupational Health and Safety to University of Gondar Comprehensive Specialized Hospital and permission was secured from the medical director. Written informed consent was obtained from mothers of each study participant. The purpose of the study was explained to study participants before securing consent. The ethical statement was carried out in accordance with the principles of the Declaration of Helsinki.

\section{Availability of Data and Material}

Data will be made available upon the reasonable request to the primary author.

\section{Acknowledgments}

We are very grateful to study participants for their permission to participate in this study and for their cooperation. We also want to acknowledge our data collectors.

\section{Author Contributions}

All authors contributed to data analysis, drafting or revising the article, gave final approval of the version to be published, and agree to be accountable for all aspects of the work.

\section{Disclosure}

The authors report no conflicts of interest in this work.

\section{References}

1. Liu L, Oza S, Hogan D, et al. Global, regional, and national causes of child mortality in 2000-13, with projections to inform post-2015 priorities: an updated systematic analysis. Lancet. 2015;385 (9966):430-440. doi:10.1016/S0140-6736(14)61698-6

2. Thiam S, Diène AN, Fuhrimann $S$, et al. Prevalence of diarrhoea and risk factors among children under five years old in Mbour, Senegal: a cross-sectional study. Infect Dis Poverty. 2017;6(1):109. doi:10.1186/ s40249-017-0323-1

3. World Health Organization. Diarrhoeal disease; 2018. Available from: https://www.who.int/news-room/fact-sheets/detail/diarrhoealdisease. Accessed August, 20192019.

4. Centers for Disease Control and Prevention. Global health Ethiopia 2019. Available from: https://www.cdc.gov/globalhealth/countries/ ethiopia/default.htm Accessed August, 232019.

5. World Health Organization. Diarrhoeal disease; 2017. Available from: https://www.who.int/news-room/fact-sheets/detail/diarrhoealdisease. Accessed November, 272019.

6. Musonda $\mathrm{C}$, et al. Factors associated with diarrheal diseases in underfive children: a case control study at arthur davison children's hospital in Ndola, Zambia. Asian Pac J Health Sci. 2017;4:228-234. doi:10.21276/apjhs.2017.4.3.34

7. Sweetser S. Evaluating the patient with diarrhea: a case-based approach Mayo Clinic Proc. 2012;87(6):596-602. doi:10.1016/j.mayocp.2012. 02.015

8. Vasconcelos MJ, Rissin A, Figueiroa JN, et al. Factors associated with diarrhea in children under five years old in the state of Pernambuco, according to surveys conducted in 1997 and 2006. Rev Saude Publica. 2018;52:48.

9. Black RE, Cousens S, Johnson HL, et al. Global, regional, and national causes of child mortality in 2008: a systematic analysis. Lancet. 2010;375(9730):1969-1987. doi:10.1016/S0140-6736(10)60 $549-1$

10. Bartram J, Brocklehurst C, Fisher MB, et al. Global monitoring of water supply and sanitation: history, methods and future challenges. Int J Environ Res Public Health. 2014;11(8):8137-8165. doi:10. 3390/ijerph110808137

11. Datta S, Singh Z, Boratne AV, et al. Knowledge and practice of handwashing among mothers of under five children in rural coastal South India. Int J Med Public Health. 2011;1(1).

12. Gupta RK, Singh P, Rani R, et al. Hand hygiene: knowledge, attitude and practices among mothers of under 5 children attending a tertiary care hospital in North India. Int J Comm Med Public Health. 2018;5 (3):1116-1121. doi:10.18203/2394-6040.ijcmph20180770

13. Shah I, Arif S, Ilyas A. Mother's knowledge and attitude associated with diarrhea in an Urban Area in Karachi, Pakistan. Int J Innovative Res Develop. 2015;2278-0211.

14. Workie HM, Sharifabdilahi AS, Addis EM. Mothers' knowledge, attitude and practice towards the prevention and home-based management of diarrheal disease among under-five children in Diredawa, Eastern Ethiopia, 2016: a cross-sectional study. BMC Pediatr. 2018;18(1):358. doi:10.1186/s12887-018-1321-6 
15. Ejemot-Nwadiaro RI, Ehiri JE, Arikpo D, et al. Hand washing promotion for preventing diarrhoea. Cochrane Database Syst Rev. 2015;9.

16. University of Gondar Comprehensive Specialized Hospital, Planning, monitoring and evaluation department report. 2019.

17. Firdaus MS, Arya IFD, Somasetia DH. Mothers' hand washing practice and diarrhea cases in children under five in Baleendah, Bandung. Althea Med J. 2015;2(2):191-198. doi:10.15850/amj. v2n2.566

18. Padhy S, Sethi R, Behera N. Mother's knowledge, attitude and practice regarding prevention and management of diarrhoea in children in Southern Odisha. Int J Contemp Pediatr. 2017;4(3):966-971. doi:10.18203/2349-3291.ijcp20171708

19. Kaba M, Ayele F. Ethnographic study of diarrhoeal diseases among under-five children in Mana district, Jimma Zone, Southwest Ethiopia. Ethiop J Health Dev. 2000;14(1):77-83. doi:10.4314/ejhd. v14i1.9932

20. Hashi A, Kumie A, Gasana J. Prevalence of diarrhoea and associated factors among under-five children in Jigjiga District, Somali Region, Eastern Ethiopia. Open J Prev Med. 2016;06:233-246. doi:10.4236/ ojpm.2016.610022

21. Diouf K, Tabatabai P, Rudolph J, et al. Diarrhoea prevalence in children under five years of age in rural Burundi: an assessment of social and behavioural factors at the household level. Glob Health Action. 2014;7:24895. doi:10.3402/gha.v7.24895

22. Kolahi AA, NABAVI M, Sohrabi MR, Epidemiology of acute diarrheal diseases among children under 5 years of age in Tehran, Iran. 2008.

23. Shah SM, Yousafzai M, Lakhani NB, Chotani RA, Nowshad G. Prevalence and correlates of diarrhea. Ind J Pediatr. 2003;70 (3):207-211. doi:10.1007/BF02725583

24. Nzioki C, Irimu G, Musoke R, English M Audit of care for children aged 6 to 59 months admitted with severe malnutrition at Kenyatta National Hospital, Kenya. Int Health. 2009;1(1):91-96. doi:10.1016/ j.inhe.2009.06.008

25. Opintan JA, Newman MJ, Ayeh-Kumi PF, et al. Pediatric diarrhea in southern Ghana: etiology and association with intestinal inflammation and malnutrition. Am J Trop Med Hyg. 2010;83(4):936-943. doi:10.4269/ajtmh.2010.09-0792

26. Ogwezzy-Ndisika AO, Solomon T, Knowledge, Attitude and Practice of Hand Washing among Mothers of Children 0-59 Months of Age in Lagos Nigeria. 2019.

27. Aigbiremolen A, Abejegah C, Ike CG, Momoh JA, Lawal-Luka RK, Abah SO. Knowledge and practice of hand washing among caregivers of under-five children in a rural nigerian community. Public Health Res. 2015;5(5):159-165.
28. Demssie A, Daniel D, Tefera A, Kindu H, Abebe S, Sanbata H. Knowledge, attitude and practice (KAP) of hand washing among mothers of under five children in Gotu Kebele Wondogenet Woreda Oromia, Ethiopia. Int J Environ Sci Technol. 2017;6(4):146-153.

29. Yadav UN. Hand washing Knowledge and Practice among mothers of under-five children in coastal Karnataka, India - A cross-sectional study. Int J Med Health Sci. 2014;3:266-271.

30. Kier PPD, Dai Y-C. Mothers' knowledge, attitudes and practices on preventing diarrhoea in Juba, South Sudan. South Sudan Med J. 2018;11(3):60-64.

31. Getachew A, et al. Diarrhea prevalence and sociodemographic factors among under-five children in rural areas of North Gondar Zone, Northwest Ethiopia. Int J Pediatr. 2018;2018:1-8. doi:10.1155/20 $18 / 6031594$

32. Shukr RI, Ali S, Khanum T, Mehmood T, et al. Is there a link between maternal illiteracy and childhood diarrhea? Rawal Med J. 2009;34(2):199-202.

33. Desta BK, Assimamaw NT, Ashenafi TD. Knowledge, practice, and associated factors of home-based management of diarrhea among caregivers of children attending under-five clinic in Fagita Lekoma District, Awi zone, Amhara regional state, Northwest Ethiopia, 2016. Nurs Res Pract. 2017;2017.

34. Mihrete TS, Alemie GA, Teferra AS. Determinants of childhood diarrhea among underfive children in Benishangul Gumuz regional state, north West Ethiopia. BMC Pediatr. 2014;14(1):102. doi:10.11 86/1471-2431-14-102

35. Baqui AH, Ahmed T. Diarrhoea and malnutrition in children. BMJ. 2006;332(7538):378. doi:10.1136/bmj.332.7538.378

36. Semba RD, Tang AM. Micronutrients and the pathogenesis of human immunodeficiency virus infection. Br J Nutr. 1999;81(3):181-189. doi:10.1017/S0007114599000379

37. Braga de Andrade JA, Fagundes-Neto U. Persistent diarrhea: still an important challenge for the pediatrician. J Pediatr (Rio J). 2011;87 (3):199-205.

38. Lwin KZ, Putra IGNE. Mothers' knowledge of the causes and prevention associated with diarrhea among under-five children in Hlaing Thar Yar Township, Yangon, Myanmar. GHMJ. 2018;2(3):76-83. doi:10.35898/ghmj-23273

39. Merga N, Alemayehu T. Knowledge, perception, and management skills of mothers with under-five children about diarrhoeal disease in indigenous and resettlement communities in Assosa District, Western Ethiopia. J Health Popul Nutr. 2015;33(1):20.
Pediatric Health, Medicine and Therapeutics

\section{Publish your work in this journal}

Pediatric Health, Medicine and Therapeutics is an international, peerreviewed, open access journal publishing original research, reports, editorials, reviews and commentaries. All aspects of health maintenance, preventative measures and disease treatment interventions are addressed within the journal. Practitioners from all disciplines are invited to submit their work as well as healthcare researchers and patient support groups. The manuscript management system is completely online and includes a very quick and fair peer-review system. Visit http://www.dovepress.com/testimonials.php to read real quotes from published authors. 